RYSZARD MIKOSZ ${ }^{1}$

\title{
Ochrona przyrody na obszarach wiejskich. Zagadnienia wybrane
}

1. Ochrona przyrody jest przedsięwzięciem złożonym i wielopłaszczyznowym. Dlatego też regulacja prawna jej dotycząca jest stosunkowo rozległa i zamieszczona została w wielu różnych aktach prawnych. Jej trzon stanowi jednak bez wątpienia ustawa z dnia 16 kwietnia 2004 r. o ochronie przyrody. ${ }^{2} \mathrm{~W}$ akcie tym, już w art. 2 ust. 1, zamieszczone zostało unormowanie, które może uchodzić za swego rodzaju definicję „ochrony przyrody”. Stanowi on bowiem, w początkowym fragmencie, że ochrona przyrody, w rozumieniu ustawy, polega na zachowaniu, zrównoważonym użytkowaniu oraz odnawianiu zasobów, tworów i składników przyrody. ${ }^{3}$

2. Treść cytowanego przepisu potwierdza tezę, że zagadnienie jest niezwykle rozległe. Oczywiste jest więc, że w założonych ramach opracowania niepodobna omówić wszystkich związanych z nim wątków. Nie bez przyczyny zatem już w tytule opracowania zawarty został zwrot ,zagadnienia wybrane”. Jego przedmiot ograniczony został bowiem w istocie rzeczy do próby poszukiwania odpowiedzi na dwa pytania. Pierwsze z nich dotyczy tego, czy regulacja prawna dotycząca ochrony przyrody ma charakter niejako uniwersalny, czy też zawiera instrumenty specyficzne odnoszące się tylko do obszarów wiejskich, albo też czy poszczególne instrumenty nią regulowane ulegają modyfikacji, w przypadku, gdy odniesione one zostają do tych obszarów. Druga kwestia, której dotyczyć będą dalsze uwagi, zamyka się z kolei w pytaniu, czy regulacja prawna dotycząca ochrony przyrody została tak ukształtowana, że może być postrzegana jako realizująca zasadę zrównoważonego rozwoju, zwłaszcza w odniesieniu do obszarów wiejskich.

\footnotetext{
Uniwersytet Śląski.

Tekst jedn. Dz.U. z 2015 r., poz. 1651 ze zm.; w toku dalszych uwag ustawa ta powoływana będzie jako u.o.p. W dalszej części art. 2 ust. 1 u.o.p. wymienione zostały wspomniane „zasoby, twory i składniki przyrody żywej i nieożywionej", która to lista obejmuje w dziewięciu punktach kolejno: dziko występujące rośliny, zwierzęta i grzyby, rośliny, zwierzęta i grzyby objęte ochroną gatunkową, zwierzęta prowadzące wędrowny tryb życia, siedliska przyrodnicze, siedliska zagrożone wyginięciem rzadkich i chronionych gatunków roślin, zwierząt i grzybów, twory przyrody żywej i nieożywionej oraz kopalne szczątki roślin i zwierząt, krajobrazu, zieleń w miastach i wsiach oraz zadrzewienia. Tylko na marginesie odnotować wypada, że niektóre użyte w art. 1 ust. 2 u.o.p. pojęcia doczekały się definicji ustawowej, co dotyczy „siedliska przyrodniczego” (art. 5 pkt 17 u.o.p.), krajobrazu (art. 5 pkt 2e u.o.p.). Dalsze szczegóły w tym zakresie trzeba jednak pominąć.
} 
3. Rozważając pierwsze z sygnalizowanych wyżej zagadnień, w punkcie wyjścia odnotować trzeba, że trudności w tym zakresie pojawiają się już przy próbie ustalenia znaczenia pojęcia „obszary wiejskie”. Mimo bowiem, że zwrot ten obficie występuje w języku prawnym, ${ }^{4}$ trudno byłoby w aktach prawnych, które do niego nawiązują znaleźć jego jedną - powszechnie przyjmowaną - definicję. Sprawę dodatkowo komplikuje fakt, że pojęcie „obszary wiejskie” nie występuje w przepisach ustawy o ochronie przyrody. Używany jest w niej natomiast termin ,wies”", który wszak również nie został bliżej sprecyzowany. Pojawia się on zresztą tylko w trzech przepisach $^{5}$ ustawy o ochronie przyrody, a mianowicie art. 2 ust. 1 pkt 8, art. 2 ust. 2 pkt 5 oraz w art. 81 .

4. Spośród wspomnianych przepisów szczególnie istotne znaczenie wydają się mieć dwa pierwsze. Artykuł 2 u.o.p. określa bowiem, o czym była już częściowo mowa wyżej, zakres przedmiotowy i cele ochrony przyrody. ${ }^{6} \mathrm{~W}$ ust. 1 przepis ten stanowi, że ochrona przyrody, w rozumieniu ustawy, polega na zachowaniu, zrównoważonym użytkowaniu oraz odnawianiu zasobów, tworów i składników przyrody, w dalszej kolejności wymieniając w 9 punktach te składniki, w tym m.in. zieleń w miastach i wsiach oraz zadrzewienia. Regulacja zawarta w 2 ust. 2 u.o.p. określa z kolei „,ele ochrony przyrody”, wyliczając je w siedmiu punktach. ${ }^{7} \mathrm{Z}$ punktu 5. wynika zaś, że celem ochrony przyrody jest m.in. „ochrona walorów krajobrazowych, zieleni w miastach i wsiach oraz zadrzewień". Wspomniany wyżej art. 81 u.o.p. dotyczy natomiast kwestii dużo bardziej szczegółowej, a mianowicie uznania terenu za park gminny. Zgodnie z treścią tego przepisu, teren położony poza obrębem miast i wsi o zwartej zabudowie, pokryty drzewostanem i nieobjęty ochroną na podstawie ustawy z dnia 23 lipca 2003 r. o ochronie zabytków i opiece nad zabyt$\mathrm{kami}^{8}{ }^{8}$ rada gminy może uznać za park gminny, jeżeli stanowi własność gminy, a jeżeli stanowi własność innego podmiotu - za zgodą właściciela.

5. Z art. 1 u.o.p. wynika, że ustawa określa cele, zasady i formy ochrony przyrody żywej i nieożywionej oraz krajobrazu. Jeśli chodzi o formy ochrony, to ich kata$\log$ (jak się wydaje zamknięty) określony został w art. 6 ust. 1. Katalog ten obejmuje 10 punktów, które można próbować usystematyzować w trzy grupy. Ochrona ta

Co dotyczy także tytułów aktów prawnych, zarówno rangi ustawowej (por. np. ustawę z dnia 20 lutego 2015 r. o wspieraniu rozwoju obszarów wiejskich z udziałem środków Europejskiego Funduszu Rolnego na rzecz Rozwoju Obszarów Wiejskich w ramach Programu Rozwoju Obszarów Wiejskich na lata 2014-2020, Dz.U. z 2015 r., poz. 349), jak i podstawowej (por. np. rozporządzenie Prezesa Rady Ministrów z dnia 18 marca 2009 r. w sprawie krajowej sieci obszarów wiejskich, Dz.U. z 2009 r. Nr 53, poz. 436 ze zm.). Liczba aktów prawnych, w których tytułach znajduje się ten zwrot jest imponująca.

5 Jeśli nie liczyć przepisu art. 27a ust. 1 u.o.p., przyznającego określone kompetencje w zakresie dotyczącym obszaru Natura 2000 ministrowi „właściwemu do spraw rozwoju wsi”.

$6 \quad$ Przepis ten został już wcześniej przywołany - por. w szczególności uwagi zawarte w przypisie 2. Przypomnieć można zatem tylko, że w art. 2 ust. 1 pkt 8 wymieniona została „zieleń w miastach i wsiach”.

$7 \quad$ Wyliczenia zawarte w art. 2 ust. 1 i 2 wydają się mieć charakter zamknięty, gdyż w treści tych przepisów nie pojawia się zwrot „w szczególności”.

8 Tekst jedn. Dz.U. z 2014 r., poz. 1446 ze zm. 
przyjmuje bowiem postać „obszarowej”, indywidualnej” oraz gatunkowej. Spośród tych trzech grup najważniejsze znaczenie, z punktu widzenia rozpatrywanego zagadnienia, mają bez wątpienia formy ochrony obszarowej, wysunięte zresztą na czoło przez ustawodawcę. Są to (w kolejności wynikającej z ustawy) parki narodowe, rezerwaty przyrody, parki krajobrazowe, obszary chronionego krajobrazu oraz obszary Natura 2000. Tylko dla porządku odnotować trzeba, że ochrona indywidualna (obiektowa) obejmuje: pomniki przyrody, stanowiska dokumentacyjne, użytki ekologiczne; oraz zespoły przyrodniczo-krajobrazowe. Ochrona gatunkowa wreszcie jest ochroną roślin, zwierząt i grzybów.

6. Analiza zawartej w ustawie o ochronie przyrody regulacji prawnej dotyczącej form ochrony obszarowej prowadzi do wniosku, że ma ona charakter uniwersalny w tym znaczeniu, że ustawodawca - kreując reżim prawny dotyczący poszczególnych form - nie przywiązuje - w sensie formalnym - żadnego znaczenia do tego, jakiego rodzaju przestrzeń (miejska, wiejska) objęta zostaje poszczególnymi formami ochrony. Nie ulega jednak wątpliwości, że co do zasady w praktyce - w zdecydowanej większości przypadków - formy te będą obejmować obszary wiejskie. Konstatacja taka wynika przede wszystkim z przesłanek warunkujących utworzenie każdej ze znanych obowiązującemu porządkowi prawnemu formy ochrony obszarowej. Wystarczy w tym zakresie sięgnąc do przykładów dotyczących parków narodowych i rezerwatów przyrody. I tak - zgodnie z art. 8 ust. 1 u.o.p. - park narodowy obejmuje obszar wyróżniający się szczególnymi wartościami przyrodniczymi, naukowymi, społecznymi, kulturowymi i edukacyjnymi, o powierzchni nie mniejszej niż 1000 ha, na którym ochronie podlega cała przyroda oraz walory krajobrazowe. $\mathrm{Z}$ kolei w myśl art. 13 ust. 1 u.o.p., rezerwat przyrody obejmuje obszary zachowane w stanie naturalnym lub mało zmienionym, ekosystemy, ostoje i siedliska przyrodnicze, a także siedliska roślin, siedliska zwierząt i siedliska grzybów oraz twory i składniki przyrody nieożywionej, wyróżniające się szczególnymi wartościami przyrodniczymi, naukowymi, kulturowymi lub walorami krajobrazowymi. ${ }^{10}$ Nietrudno dostrzec, że wśród tych przesłanek wymienione zostały takie elementy (wartości), które trudno byłoby w znaczącej ilości znaleźć w przestrzeni objętej granicami miast, co potwierdzają przykłady zaczerpnięte z treści aktów tworzących parki narodowe. ${ }^{11}$ Jeszcze bardziej okoliczność ta ujawnia się w przypadku

9 Terminy takie nie pojawiają się jednak w treści przepisów ustawy o ochronie przyrody.

10 Podobnie jest w przypadku pozostałych form ochrony obszarowej. Stosownie bowiem do treści art. 16 ust. 1 u.o.p., park krajobrazowy obejmuje obszar chroniony ze względu na wartości przyrodnicze, historyczne i kulturowe oraz walory krajobrazowe w celu zachowania, popularyzacji tych wartości w warunkach zrównoważonego rozwoju. W myśl z kolej art. 23 ust. 1 u.o.p., obszar chronionego krajobrazu obejmuje tereny chronione ze względu na wyróżniający się krajobraz o zróżnicowanych ekosystemach, wartościowe ze względu na możliwość zaspokajania potrzeb związanych z turystyką i wypoczynkiem lub pełnioną funkcją korytarzy ekologicznych. Zgodnie natomiast z art. 25 ust.1 u.o.p., sieć obszarów Natura 2000 obejmuje: obszary specjalnej ochrony ptaków, specjalne obszary ochrony siedlisk oraz obszary mające znaczenie dla Wspólnoty.

11 I tak z § 2 rozporządzenia Rady Ministrów z dnia 1 kwietnia 2003 r. w sprawie Tatrzańskiego Parku Narodowego (Dz.U. z 2003 r. Nr 55, poz. 599) jasno wynika, że zdecydowaną większość tego Parku stanowią tereny położone 
rezerwatów przyrody, o czym świadczy chociażby treść wydanego na podstawie art. 14 u.o.p. rozporządzenia Ministra Środowiska z dnia 30 marca 2005 r. w sprawie rodzajów, typów i podtypów rezerwatów przyrody. ${ }^{12}$ Analizując bowiem załącznik do tego rozporządzenia określający rodzaje i podtypy rezerwatów przyrody nietrudno dostrzec, iż w istocie rzeczy chodzi w tym przypadku w zasadzie wyłącznie o obszary, które mogą być położone jedynie w granicach gmin wiejskich.

7. Miejsce położenia określonej formy obszarowej ochrony przyrody może mieć jednak znaczenie dla jej reżimu ochronnego. Spostrzeżenie to dotyczy w szczególności parków krajobrazowych oraz obszarów chronionego krajobrazu, co wiąże się ze sposobem, w jaki ustanawiany jest reżim prawny tych przestrzeni. O ile bowiem w przypadku parku narodowego i rezerwatu przyrody reziim ochronny wynika wprost z ustawy, ${ }^{13}$ o tyle inaczej sytuacja wygląda odnośnie do parku krajobrazowego i obszaru chronionego krajobrazu. Wtedy bowiem, w uchwałach tworzących oba wspomniane rodzaje form ochrony obszarowej, organ je tworzący, którym jest sejmik województwa, na podstawie odpowiednio art. 16 ust. 3 i 23 ust. 2 u.o.p., określa m.in. zakazy właściwe dla danego parku krajobrazowego lub jego części, wybierając je spośród zakazów wymienionych w art. 17 ust. 1 u.o.p. (w przypadku parku krajobrazowego) oraz w art. 24 ust. 1 (w przypadku obszaru chronionego krajobrazu). Kryterium wyboru nie jest przy tym dowolne, gdyż mają to być zakazy „,wynikające z potrzeb ochrony” obu tych rodzajów obszarów. Tytułem przykładu

w gminach wiejskich (Bukowina Tatrzańska, Kościelisko, Poronin), a tereny znajdujące się w granicach miasta Zakopane stanowią w Parku znikomy procent. Z kolei z treści § 2 rozporządzenia Rady Ministrów z dnia 8 sierpnia 1997 r. w sprawie Ojcowskiego Parku Narodowego (Dz.U. z 1997 r. Nr 99, poz. 607) wynika, że Park ten położony jest wyłącznie w granicach gmin wiejskich (Jerzmanowice, Skała, Sułoszowa, Wielka Wieś, Zielonki).

Dz.U. z 2005 r. Nr 60, poz. 533. Na marginesie odnotować przy tym należy, że przywołane akty wydane zostały na podstawie nieobowiązującej już ustawy z dnia 16 października 1991 r. o ochronie przyrody (ostatni tekst jedn. (Dz.U. z 2001 r. Nr 99, poz. 1079, ze zm.), zachowały jednak moc obowiązującą (por. art. 153 u.o.p.). Pod rządem aktualnego stanu prawnego parki narodowe tworzone mają być w drodze ustawy (por. art. 10 ust. 3 u.o.p. w brzmieniu nadanym ustawą z dnia 18 sierpnia $2011 \mathrm{r}$. o zmianie ustawy o ochronie przyrody oraz niektórych innych ustaw, Dz.U. z 2011 r. Nr 224, poz. 1337), tym niemniej określenie i zmiana granic parku narodowego nastąpić musi w drodze rozporządzenia Rady Ministrów, które określać powinno jego obszar, przebieg granicy, otulinę i nieruchomości Skarbu Państwa nieoddawane w użytkowanie wieczyste parkowi narodowemu (art. 10 ust. 1 u.o.p.). Rozwiązanie taki stanowi swego rodzaju kuriozum i doczekało się już zasadnej krytyki w literaturze (por. w szczególności A. Lipiński, Park narodowy jako forma ochrony przyrody. Krytyczna analiza stanu prawnego, [w:] Ocena stanu prawnego funkcjonowania polskich parków narodowych, Warszawa 2015, s. 149 i n. oraz K. Mordasiewicz-Toczyska, Prawne aspekty tworzenia, likwidacji i zmiany granic parku narodowego, [w:] Ochrona przyrody. Uwarunkowania prawne, organizacyjne, społeczne i intelektualne wykorzystywania jej zasobów, Warszawa 2015, s. 71 i n.

13 Został on określony przede wszystkim w art. 15 u.o.p. Trzeba jednak pamiętać, że stosownie do treści art. 18 ust. 1 u.o.p., m.in. dla parków narodowych i rezerwatów przyrody sporządza się i realizuje plan ochrony, który konkretyzuje niektóre zakazy ujęte w ustawie w sposób ogólny. Zgodnie bowiem z art. 20 ust. 3 u.o.p., plan taki powinien m.in. zawierać określenie działań ochronnych na obszarach ochrony ścisłej, czynnej i krajobrazowej, z podaniem rodzaju, zakresu i lokalizacji tych działań (pkt 4), wskazanie obszarów i miejsc udostępnianych dla celów naukowych, edukacyjnych, turystycznych, rekreacyjnych, sportowych, amatorskiego połowu ryb i rybactwa oraz określenie sposobów ich udostępniania (pkt 5) oraz wskazanie miejsc, w których może być prowadzona działalność wytwórcza, handlowa i rolnicza (pkt 6). Szczegóły w tym zakresie określa rozporządzenie Ministra Środowiska z dnia 12 maja 2005 r. w sprawie sporządzania projektu planu ochrony dla parku narodowego, rezerwatu przyrody i parku krajobrazowego, dokonywania zmian w tym planie oraz ochrony zasobów, tworów i składników przyrody (Dz.U. z 2005 r. Nr 94, poz. 794). 
odnotować można w tym kontekście, że zgodnie z art. 17 ust. 1 u.o.p., w parku krajobrazowym mogą być wprowadzone zakazy: wylewania gnojowicy, z wyjątkiem nawożenia własnych gruntów rolnych (pkt 10) oraz prowadzenia chowu i hodowli zwierząt metodą bezściółkową (pkt 11). Nie zawsze odnosić się one będą do obszarów wiejskich, jednak w zdecydowanej większości przypadków taki właśnie stan rzeczy będzie miał miejsce.

8. Przechodząc z kolei do drugiej z sygnalizowanych na początku kwestii, zamykającej się w pytaniu, czy regulacja prawna dotycząca ochrony przyrody została tak ukształtowana, że może być postrzegana jako realizująca zasadę zrównoważonego rozwoju, zwłaszcza w odniesieniu do obszarów wiejskich, należy w punkcie wyjścia odnotować, że sama zasada zrównoważonego rozwoju choć dostrzeżona przez ustawodawcę konstytucyjnego ${ }^{14}$ nie doczekała się powszechnej definicji, mogącej - bez wątpliwości znaleźć zastosowanie w całym porządku prawnym. Co prawda

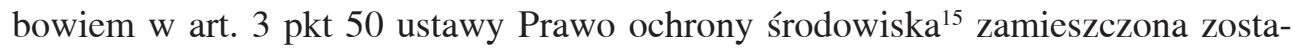
ła definicja ,zrównoważony rozwój”, ${ }^{16}$ ale odnosi się ona - formalnie rzecz biorąc - tylko do tej ustawy (co wynika ze zwrotu „Ilekroć w ustawie jest mowa o:”, rozpoczynającego art. 3 p.o.ś.). Jest zatem kwestią dyskusyjną, czy można (trzeba) ją także brać pod uwagę w przypadku wykładni przepisów zawartych w innych aktach normatywnych, które nawiązują do „zrównoważonego rozwoju”, zagadnienie to jednak ma charakter dyskusyjny, którego niepodobna w tym miejscu rozwinąć. ${ }^{17}$

14 Zasada ta wprost wymieniona została w art. 5 Konstytucji Rzeczypospolitej Polskiej z dnia 2 kwietnia 1997 r., (Dz.U. z 1997 r. Nr 78, poz. 483 ze zm.), zamieszczonym w Rozdziale I zatytułowanym „Rzeczpospolita”. Stosownie do treści tego przepisu, Rzeczpospolita Polska strzeże niepodległości i nienaruszalności swojego terytorium, zapewnia wolności i prawa człowieka i obywatela oraz bezpieczeństwo obywateli, strzeże dziedzictwa narodowego oraz zapewnia ochronę środowiska, kierując się zasadą zrównoważonego rozwoju. Takie usytuowanie art. 5 Konstytucji wyraźnie wskazuje, że zasadę zrównoważonego rozwoju traktować trzeba jako zasadę ustrojową, odnoszącą się do podstawowych zadań państwa, a jednocześnie określającą ochronę środowiska jako jedno z podstawowych zadań władz publicznych i obywateli (Z. Bukowski, Konstytucyjne podstawy obowiązków państwa w zakresie ochrony środowiska, Prawo i Środowisko z 2002 r., nr 4, s. 63-73. Por. także J. Stelmasiak, A. Wąsikowska, [w:] Prawo ochrony środowiska, J. Stelmasiak (red.), Warszawa 2010, s. 27). Trafne wydaje się również zapatrywanie przyjmujące, że zasada zróżnicowanego rozwoju ma charakter dyrektywalny, co oznacza, iż ma ona charakter wiążący dla wszystkich organów państwa, a zatem powinna być uwzględniania zarówno w procesie stanowienia, jak i stosowania prawa, w tym ostatnim zakresie w toku wykładni przepisów prawa (tak materialnego, jak i procesowego), których treść budzi wątpliwości interpretacyjne (por. m.in.: P. Winczorek, Komentarz do Konstytucji Rzeczypospolitej Polskiej z dnia 2 kwietnia 1997 r., Warszawa 2000, s. 18; M. Górski, [w:] M. Górski, M. Pchałek, W. Radecki, J. Jerzmański, M. Bar, S. Urban, J. Jendrośka, Prawo ochrony środowiska. Komentarz, Warszawa 2011, s. 129-130. Stanowisko takie podzielił też Trybunał Konstytucyjny w wyroku z dnia 13 maja 2009 r., sygn. akt Kp 2/09, OTK-A z 2009 r., nr 5, poz. 66.

15 Ustawa z dnia 27 kwietnia 2001 r. - Prawo ochrony środowiska (tekst jedn. Dz.U. z 2016 r., poz. 622); ustawa ta będzie dalej przywoływana jako p.o.ś.

16 Wynika z niej, że przez zrównoważony rozwój rozumie się taki rozwój społeczno-gospodarczy, w którym następuje proces integrowania działań politycznych, gospodarczych i społecznych, z zachowaniem równowagi przyrodniczej oraz trwałości podstawowych procesów przyrodniczych, w celu zagwarantowania możliwości zaspokajania podstawowych potrzeb poszczególnych społeczności lub obywateli zarówno współczesnego pokolenia, jak i przyszłych pokoleń.

17 Odnotować w tym kontekście trzeba, że czasem przepisy prawa wprost odsyłają do niej (por. np. art. 2 pkt 2 ustawy z dnia 27 marca 2003 r. o planowaniu i zagospodarowaniu przestrzennym, tekst jedn. Dz.U. z 2016 r., poz. 778). 
9. Istotniejszym problemem, na który trzeba zwrócić uwagę, jest bowiem okoliczność, że w ustawie o ochronie przyrody obok pojęcia „zrównoważony rozwój”, ${ }^{18}$ pojawiają się także inne zwroty, a mianowicie ,zrównoważone użytkowanie zasobów, tworów i składników przyrody”, ${ }^{19}$,zrównoważone użytkowanie różnorodności biologicznej" ${ }^{20}$ oraz ,zrównoważone trwanie populacji gatunków i siedlisk przyrodniczych". ${ }^{21}$ Powstaje zatem najpierw pytanie, jak rozumieć te zwroty, następnie zaś, w jakiej relacji pozostają one do pojęcia „zrównoważony rozwój”. Próbując udzielić na nie odpowiedzi, odnotować trzeba, że w literaturze przedmiotu wymienione wyżej pojęcia traktowane są wręcz jako swego rodzaju synonimy, ${ }^{22}$ albo też jako pozostające ze sobą w ścisłym związku. ${ }^{23}$ Ostatnio przywołany pogląd zasługuje, jak się wydaje, na aprobatę. Nie sposób bowiem nie dostrzec, w jak bliskim związku pozostają pojęcia „zrównoważony rozwój” i ,zróżnicowane użytkowanie”, chociażby ze względu na fakt, że to pierwsze wprost nawiązuje do ,zachowania równowagi przyrodniczej ${ }^{24}$ oraz trwałości podstawowych procesów przyrodniczych". ${ }^{25}$

10. Jeśli sygnalizowane ostatnio wątpliwości pozostawić na uboczu, to odnotować trzeba dalej, że mimo, iż pojęcie „zrównoważony rozwój”, pojawiło się w powszechnym użyciu relatywnie niedawno, doczekało się już olbrzymiej ilości wypowiedzi zarówno w literaturze ${ }^{26}$ jak i - w mniejszym stopniu - w orzecznictwie. ${ }^{27}$ Nadal jednak brak jednolitego powszechnie aprobowanego stanowiska co do spo-

Zostało ono użyte w przywołanym już wyżej art. 16 ust. 1 u.o.p., określającym przesłanki tworzenia parku krajobrazowego. Nigdzie w ustawie nie została natomiast wymieniona „zasada zrównoważonego rozwoju”.

Zwrot ten występuje w przywołanym już wyżej art. 2 ust. 1 u.o.p., określającym zakres ochrony przyrody.

Zgodnie z art. 5 pkt 16 u.o.p., różnorodność biologiczna oznacza zróżnicowanie żywych organizmów występujących w ekosystemach, w obrębie gatunku i między gatunkami oraz zróżnicowanie ekosystemów. Przepis art. 3 u.o.p., określający środki, za pomocą których realizowane są cele ochrony przyrody wskazuje wśród nich m.in. realizację programu ochrony i zrównoważonego użytkowania różnorodności biologicznej wraz z planem działań. Program ten, którego projekt sporządza minister właściwy do spraw środowiska, zatwierdza Rada Ministrów w drodze uchwały (por. art. 111 u.o.p.).

21 Pojawia się on w definicji ustawowej pojęcia „integralność obszaru Natura 2000”, przez co należy rozumieć spójność czynników strukturalnych i funkcjonalnych warunkujących zrównoważone trwanie populacji gatunków i siedlisk przyrodniczych, dla ochrony których zaprojektowano lub wyznaczono obszar Natura 2000.

Komentując treść art. 2 u.o.p. K. Gruszecki (Ustawa o ochronie przyrody. Komentarz do art. 2, Wydanie III, LEX 2013, wydanie elektroniczne) stwierdza wręcz, że w przepisie tym doszło do odesłania przez ustawodawcę do pojęcia zrównoważony rozwój.

23 Komentując przepis art. 2 u.o.p. W. Radecki (Ustawa o ochronie przyrody. Komentarz, Wydanie III, Warszawa 2012, s. 58), podnosi, że „koncepcja zróżnicowanego użytkowania zasobów, tworów i składników przyrody jest związana z ideą zrównoważonego rozwoju.

24 Pojęcie „równowaga przyrodnicza” zdefiniowane zostało w art. 3 pkt 32 p.o.ś. i rozumie się przez to stan, w którym na określonym obszarze istnieje równowaga we wzajemnym oddziaływaniu: człowieka, składników przyrody żywej i układu warunków siedliskowych tworzonych przez składniki przyrody nieożywionej. Por. definicję „zrównoważonego rozwoju” przytoczoną w przypisie 16.

Por. przede wszystkim Z. Bukowski, Zrównoważony rozwój w systemie prawa, Toruń 2009 oraz wskazaną tam literaturę. Por. także J. Ciechanowicz-McLean, K. Urbańska, Zasada zrównoważonego rozwoju w prawie polskim i międzynarodowym, Gdańsk 2009. Liczba opracowań cząstkowych podejmujących kwestie szczegółowe związane z zasadą zrównoważonego rozwoju jest spora i nadal rośnie (por. R. Mikosz, [w:] G. Dobrowolski, A. Lipiński, R. Mikosz, G. Radecki, Zrównoważony rozwój jako czynnik determinujący prawne podstawy zarządzania geologicznymi zasobami środowiska, G. Dobrowolski (red.), Katowice 2016, s. 14 i n.

Por. G. Dobrowolski, R. Mikosz, Zasada zrównoważonego rozwoju w orzecznictwie sądów administracyjnych, [w:] Działalność gospodarcza na obszarach chronionych, R. Biskup, M. Pytel, R. Rudnicki, J. Trzewik (red.), Lublin 2014, s. 113 i n. 
sobu jego rozumienia. Odnosząc się do definicji „zrównoważony rozwój” zawartej w przywołanym już wyżej art. 3 pkt 50 p.o.ś., stwierdzić wypada, że kluczowe znaczenie wydaje się mieć $\mathrm{w}$ jej ramach położenie nacisku na proces integrowania działań politycznych, gospodarczych i społecznych, z zachowaniem równowagi przyrodniczej oraz trwałości podstawowych procesów przyrodniczych. Podtrzymać trzeba zarazem wcześniej wyrażony pogląd, ${ }^{28}$ że jeśli słowo „rozwój” postrzegać jako „proces przeobrażeń, zmian, przechodzenia do stanów lub form bardziej złożonych, lub pod pewnym względem doskonalszych”, ${ }^{29}$ a pojęcie ,zrównoważyć” pojmować jako ,doprowadzenie do stanu równowagi, zniesienie, wyrównanie działania jakiejś siły, utrzymanie w równowadze", ${ }^{30}$ to połączenie obu tych pojęć skłania do przyjęcia tezy, że w przypadku ,zrównoważonego rozwoju” chodzi o proces przeobrażeń zmierzających do stanów lepszych (doskonalszych) od wcześniejszych, który to proces ma jednak uwzględniać potrzebę „równowagi”. Wspomnianą wyżej „,integrację” trzeba zatem postrzegać jako ,zespalanie się elementów w całość, scalanie czegoś". ${ }^{31} \mathrm{~W}$ przypadku zrównoważonego rozwoju chodzi o scalanie rozwoju społeczno-gospodarczego z potrzebą ochrony środowiska, określoną w tym przypadku jako zachowanie równowagi przyrodniczej oraz trwałości podstawowych procesów przyrodniczych, w celu zagwarantowania możliwości zaspokajania podstawowych potrzeb poszczególnych społeczności lub obywateli, zarówno współczesnego pokolenia, jak i przyszłych pokoleń.

11. Odnosząc poczynione ostatnio spostrzeżenia do materii będącej przedmiotem analizy w ramach drugiego z wcześniej sformułowanych pytań, rozważyć należy, czy formy ochrony przyrody przewidziane w ustawie o ochronie zostały tak ukształtowane, że realizują wspomnianą integrację. W tym kontekście ustalić trzeba przede wszystkim, czy obowiązujący porządek prawny dopuszcza możliwość prowadzenia „działań gospodarczych”32 w obrębie obszarów objętych ochroną na podstawie ustawy o ochronie przyrody.

12. Rozpatrując tę kwestię, już w punkcie wyjścia podkreślić należy, że ustawodawca - kreując instrumenty ochrony przyrody - nie przyjął założenia, iż co do zasady realizacja tej ochrony całkowicie wyklucza prowadzenie działalności gospodarczej. Spostrzeżenie to w mniejszym lub większym stopniu dotyczy także wszyst-

28 Por. R. Mikosz [w:] Zrównoważony rozwój..., op. cit., s. 25 i n.

29 Słownik języka polskiego, M. Szymczak (red.), t. 3, Warszawa 1981, s. 131, hasło „rozwój”.

30 Ibidem, s. 1060, hasła „zrównoważony” i „zrównoważyć”.

31 Słownik języka polskiego, M. Szymczak (red.), t. 1, Warszawa 1978, s. 796-797, hasło „integracja”.

32 Zwrot „działania gospodarcze” został wprost użyty w treści art. 3 pkt 50 p.o.ś. Wydaje się, że należy go rozumieć szeroko i nie traktować go jako synonimu do „działalności gospodarczej” zdefiniowanej w ustawie z dnia 2 lipca 2004 r. o swobodzie działalności gospodarczej (tekst jedn. Dz.U. z 2016 r., poz. 1829). Stosownie bowiem do treści art. 2 tej ustawy, działalnościa gospodarczą jest zarobkowa działalność wytwórcza, budowlana, handlowa, usługowa oraz poszukiwanie, rozpoznawanie i wydobywanie kopalin ze złóż, a także działalność zawodowa, wykonywana w sposób zorganizowany i ciągły. Świadczy o tym chociażby kontekst, w jakim w art. 3 pkt 50 p.o.ś. użyty został zwrot „działania gospodarcze”, wymienione obok działań „politycznych” i „społecznych”. 
kich obszarowych form tej ochrony, nie wyłączając instrumentów o najbardziej rygorystycznym reżimie prawnym. Znajduje to wyraźnie potwierdzenie w przepisach wyznaczających reżim prawny poszczególnych form ochrony. I tak, zgodnie z treścią art. 15 ust. 1 u.o.p., określającego zakazy obowiązujące na terenie parków narodowych i rezerwatów przyrody, na ich terenie zabrania się m.in. (pkt 11) prowadzenia działalności wytwórczej, handlowej i rolniczej, z wyjątkiem jednak miejsc wyznaczonych w planie ochrony. Oznacza to, innymi słowy, że zakaz prowadzenia takiej działalności nie ma charakteru bezwzględnego. Konstatację tę potwierdza treść niektórych przepisów przywołanego już wyżej rozporządzenia Ministra Środowiska z dnia 12 maja 2005 r. w sprawie sporządzania projektu planu ochrony dla parku narodowego, rezerwatu przyrody i parku krajobrazowego, dokonywania zmian w tym planie oraz ochrony zasobów, tworów i składników przyrody. ${ }^{33} \mathrm{Z}$ jego $\S 32$ ust. 1 pkt 2, znajdującego się w rozdziale 6. regulującym zakres i sposoby ochrony zasobów, tworów i składników przyrody w parku narodowym i rezerwacie przyrody, wynika bowiem, że ochrona na obszarach objętych ochroną krajobrazową polega w szczególności na modyfikowaniu sposobów gospodarczego użytkowania obszarów, w tym dostosowaniu gospodarki rolnej, leśnej, rybackiej i turystyki, w sposób uwzględniający potrzeby ochrony zasobów, tworów i składników przyrody. Jest zatem poza sporem, że ochrona zarówno parku narodowego, jak i parku krajobrazowego, nie polega na całkowitym wyłączeniu możliwości gospodarczego wykorzystania takich terenów. Nie można zarazem tracić z pola widzenia, że w istocie rzeczy od wszystkich zakazów obowiązujących zarówno na terenie parku narodowego, jak i rezerwatu przyrody, mogą zostać ustanowione odstępstwa ${ }^{34}$ wtedy, gdy istnieje potrzeba realizacji inwestycji liniowych celu publicznego, w przypadku braku rozwiązań alternatywnych i po zagwarantowaniu kompensacji przyrodniczej. ${ }^{35}$

13. Ostatnio podnoszona kwestia jeszcze wyraźniej widoczna jest w przypadku parku krajobrazowego. Kluczowe znaczenie w tym zakresie wydaje się mieć zwłaszcza art. 16 ust. 6 u.o.p., z którego wprost wynika, że grunty rolne i leśne oraz inne nieruchomości znajdujące się $\mathrm{w}$ granicach parku krajobrazowego pozostawia się w gospodarczym wykorzystaniu. Potwierdza to również treść $§ 34^{36}$ wspomnianego wyżej rozporządzenia Ministra Środowiska z dnia 12 maja 2005 r. Z pkt 9 tego

33 Por. przypis 13.

34 Zezwolenia na te odstępstwa wydawane są w drodze decyzji administracyjnej, na czas określony, nie dłuższy niż 5 lat (art. 15 ust. 6 u.o.p.). Organami uprawnionymi do wydania takiej decyzji są minister właściwy do spraw środowiska (Minister Środowiska), w przypadku parku narodowego albo Generalny Dyrektor Ochrony Środowiska w odniesieniu do rezerwatu przyrody (art. 15 ust. 3 i 4 u.o.p.).

Stosownie do treści art. 3 pkt 8 p.o.ś., przez kompensację przyrodniczą rozumie się zespół działań obejmujących w szczególności roboty budowlane, roboty ziemne, rekultywację gleby, zalesianie, zadrzewianie lub tworzenie skupień roślinności, prowadzących do przywrócenia równowagi przyrodniczej lub tworzenie skupień roślinności, prowadzących do przywrócenia równowagi przyrodniczej na danym terenie, wyrównania szkód dokonanych w środowisku przez realizację przedsięwzięcia i zachowanie walorów krajobrazowych. Został on zamieszczony w rozdziale 7 rozporządzenia, regulującym zakres i sposoby ochrony zasobów, tworów i składników przyrody w parku krajobrazowym. 
przepisu wynika bowiem m.in. to, że plan ochrony parku krajobrazowego powinien obejmować określenie sposobów ochrony zasobów, tworów i składników przyrody obejmujące m.in. ochronę walorów przyrodniczych obszarów produkcji rolniczej i leśnej przez: a) stosowanie dobrych praktyk rolniczych, b) uwzględnianie potrzeb ochrony przyrody w gospodarce leśnej oraz c) wdrażanie przedsięwzięć rolnośrodowiskowych i rozwój rolnictwa ekologicznego. Nie ulega zatem wątpliwości, że na obszarze parku może być w szczególności wykonywana działalność rolnicza i leśna. Zachować przy tym trzeba jednak świadomość faktu, że „działalność rolnicza” nie zawsze przybierze postać działalności gospodarczej, ${ }^{37} \mathrm{z}$ kolei zaś nie jest dostatecznie jasne, czy „działalność leśna” może być utożsamiana z ,gospodarką leśną”.38

14. Przykłady takie można przywołać w szerszym zakresie. ${ }^{39}$ Dowodzą one, że w przypadku wszystkich form ochrony przyrody co do zasady nie została całkowicie wykluczona możliwość prowadzenia działalności gospodarczej, przede wszystkim przybierającej postać działalności rolniczej i leśnej. Tego rodzaju działalność jest zaś - z istoty swej - prowadzona przede wszystkim w obrębie obszarów wiejskich. Dotyczy to nawet parku narodowego, czego dowodzi regulacja zawarta w art.

Np. art. 2 pkt 3 ustawy z dnia 11 kwietnia 2003 r. o kształtowaniu ustroju rolnego (Dz.U. z 2012 r., poz. 803 ze zm.), definiuje „prowadzenie działalności rolniczej” - jako prowadzenie działalności wytwórczej w rolnictwie w zakresie produkcji roślinnej lub zwierzęcej, w tym produkcji ogrodniczej, sadowniczej i rybnej. Jest to jedno z podstawowych pojęć używanych w ustawie z dnia 28 września $1991 \mathrm{r}$. o lasach (tekst jedn. Dz.U. z 2015 r., poz. 2100 ze zm.). Zgodnie z jej art. 6 ust. 1 pkt 1, gospodarka leśna oznacza działalność leśną w zakresie urządzania, ochrony i zagospodarowania lasu, utrzymania i powiększania zasobów i upraw leśnych, gospodarowania zwierzyną, pozyskiwania - z wyjątkiem skupu - drewna, żywicy, choinek, karpiny, kory, igliwia, zwierzyny oraz płodów runa leśnego, a także sprzedaż tych produktów oraz realizację pozaprodukcyjnych funkcji lasu. Ustawie znane jest też pojęcie „trwale zrównoważonej gospodarki leśnej”, oznaczające działalność zmierzającą do ukształtowania struktury lasów i ich wykorzystania w sposób i tempie zapewniającym trwałe zachowanie ich bogactwa biologicznego, wysokiej produkcyjności oraz potencjału regeneracyjnego, żywotności i zdolności do wypełniania, teraz i w przyszłości, wszystkich ważnych ochronnych, gospodarczych i socjalnych funkcji na poziomie lokalnym, narodowym i globalnym, bez szkody dla innych ekosystemów (art. 6 ust. 1 pkt 1a). Szczegółów w tym zakresie niepodobna jednak rozwinąć.

39 Odnoszą się one także do wspomnianych dotychczas jedynie marginalnie obszarów Natura 2000. Z art. 33 ust. 1 u.o.p. wynika bowiem, że co do zasady zabronione jest w nich podejmowanie działań mogących, osobno lub w połączeniu z innymi działaniami, znacząco negatywnie oddziaływać na cele ochrony obszaru Natura 2000, w tym w szczególności: pogorszyć stan siedlisk przyrodniczych lub siedlisk gatunków roślin i zwierząt, dla których ochrony wyznaczono obszar Natura 2000 lub wpłynąć negatywnie na gatunki, dla których ochrony został wyznaczony obszar Natura 2000, lub pogorszyć integralność obszaru Natura 2000 lub jego powiązania z innymi obszarami. Zarazem jednak ustawodawca dopuścił możliwość udzielenia zezwolenia na odstępstwo od zakazów obowiązujących na obszarach Natura 2000, co wynika z art. 34 u.o.p. Jeżeli bowiem przemawiają za tym konieczne wymogi nadrzędnego interesu publicznego, w tym wymogi o charakterze społecznym lub gospodarczym, i wobec braku rozwiązań alternatywnych, właściwy miejscowo regionalny dyrektor ochrony środowiska, a na obszarach morskich - dyrektor właściwego urzędu morskiego, może zezwolić na realizację planu lub działań, mogących znacząco negatywnie oddziaływać na cele ochrony obszaru Natura 2000 lub obszary znajdujące się na liście, o której mowa w art. 27 ust. 3 pkt 1, zapewniając wykonanie kompensacji przyrodniczej niezbędnej do zapewnienia spójności i właściwego funkcjonowania sieci obszarów Natura 2000. Szczegółów w tym zakresie niepodobna rozwinąć (por. m.in. A. Habuda, Ochrona przyrody a działalnośc gospodarcza na obszarach Natura 2000, [w:] Gospodarcze prawo środowiska, J. Ciechanowicz-McLean, T. Bojar-Fijałkowski (red.), Gdańsk 2009, s. 175 i n., K. Gruszecki, Ograniczenia prawne w realizacji inwestycji w związku z wyznaczeniem obszarów Natura 2000, „Zeszyty Naukowe Sądownictwa Administracyjnego” 2011, nr 2, s. 34 i n., E.K. Czech, Ograniczanie wolności działalności gospodarczej na obszarach Natura 2000, [w:] Problemy wdrażania systemu Natura 2000 w Polsce, A. Kaźmierska-Patrzyczna, M.A. Król (red.), Szczecin - Łódź - Poznań 2013, s. 495 i n.). 
8h ust. 1 pkt 11 u.o.p., z której wynika, że przychodami parku narodowego są m.in. wpływy wynikające z prowadzenia działalności rolniczej.

15. Nie ulega wątpliwości, że regulacja prawna dotycząca poszczególnych form przyrody, przede wszystkim zaś będący jej immanentną częścią system zakazów, została tak ukształtowana, aby możliwe było zrealizowanie ochrony przestrzeni objętych tymi formami. Inne rodzaje działalności muszą zostać podporządkowane celom ochronnym i jak to wynika z przywołanych wyżej przykładów, dopuszczone zostały przez ustawodawcę jedynie o tyle, o ile ich podejmowanie i prowadzenie nie wywrze negatywnego wpływu na ochronę. W ustawie o ochronie przyrody można jednak dostrzec, jak się wydaje, także przypadki, kiedy to dochodzić może do swego rodzaju „odwrócenia priorytetów”, co ilustrują rozwiązania odnoszące się do parku krajobrazowego oraz obszaru chronionego krajobrazu. Znajdują one zastosowanie już na etapie tworzenia obu tych form ochrony, a polegają - najogólniej rzecz ujmując - na odmowie uzgodnienia projektu uchwały ustanawiającej taką formę. ${ }^{40} \mathrm{I}$ tak, stosownie do art. 16 ust. 4b u.o.p., ${ }^{41}$ rada gminy może odmówić uzgodnienia projektu uchwały, o której mowa w ust. $3{ }^{42}$ wyłącznie w przypadku, gdy przyjęcie tej uchwały prowadziłoby do ograniczenia możliwości rozwojowych gminy wynikających z ustaleń studium uwarunkowań i kierunków zagospodarowania przestrzennego ${ }^{43}$ lub miejscowego planu zagospodarowania przestrzennego $\mathrm{W}$ stopniu nieproporcjonalnym do wartości, jakie park krajobrazowy ma chronić. Identyczne co do konstrukcji i treści normatywnej rozwiązanie przyjęte zostało art. 23 ust. 3 b u.o.p. ${ }^{44}$ Treść tych przepisów zdaje się zatem dopuszczać sytuację, w której działalność gospodarcza może uzyskać priorytet przed wymaganiami o charakterze ochronnym.

16. Konkludując, stwierdzić wypada, odnosząc się do sformułowanych na wstępie pytań, że - po pierwsze - ustawodawca nie przewiduje „specjalnego” reżimu ochrony przyrody na obszarach wiejskich, gdyż reżim przewidziany ustawą o ochro-

40 Przypomnieć trzeba, że organem właściwym do podjęcia takiej uchwały jest sejmik województwa, co dotyczy zarówno parku krajobrazowego, jak i obszaru chronionego krajobrazu.

41 Przepis ten obowiązuje od niedawna, gdyż został dodany do ustawy o ochronie przyrody przez art. 9 pkt 2 lit. c ustawy z dnia 24 kwietnia 2015 r. o zmianie niektórych ustaw w związku ze wzmocnieniem narzędzi ochrony krajobrazu (Dz.U. z 2015 r., poz. 774), z mocą obowiązującą od dnia 11 września 2015 r.

42 Stosownie do art. 16 ust. 3 u.o.p., utworzenie parku krajobrazowego lub powiększenie jego obszaru następuje w drodze uchwały sejmiku województwa, która określa jego nazwę, obszar, przebieg granicy i otulinę, jeżeli została wyznaczona, szczególne cele ochrony oraz zakazy właściwe dla danego parku krajobrazowego lub jego części, wybrane spośród zakazów, o których mowa w art. 17 ust. 1, wynikające z potrzeb jego ochrony.

Stosownie do treści art. 10 ust. 2 ustawy o planowaniu i zagospodarowaniu przestrzennym (por. przypis 17), w studium określa się w szczególności: kierunki i wskaźniki dotyczące zagospodarowania oraz użytkowania terenów, w tym tereny przeznaczone pod zabudowę oraz tereny wyłączone spod zabudowy (pkt 1 b), kierunki rozwoju systemów komunikacji i infrastruktury technicznej (pkt 5), obszary, na których rozmieszczone będą inwestycje celu publicznego o znaczeniu lokalnym (pkt 6) oraz obszary, na których rozmieszczone będą inwestycje celu publicznego o znaczeniu ponadlokalnym, zgodnie z ustaleniami planu zagospodarowania przestrzennego województwa i ustaleniami programów, o których mowa w art. 48 ust. 1 ustawy (pkt 7). Por. przypis 38. 
nie przyrody w tym znaczeniu w jednakowym stopniu odnosi się do całego terenu objętego ochroną obszarową, że nie ulega zróżnicowaniu ze względu na rodzaj obszarów podlegających ochronie. Można oczywiście zastanawiać się, czy jest to rozwiązanie właściwe, wydaje się jednak, że zdecydowanie więcej argumentów przemawia w tym przypadku na rzecz odpowiedzi twierdzącej. Przede wszystkim więc, o czym była już mowa wyżej, samo pojęcie ,obszary wiejskie” pozostaje de lege lata niedookreślone i wydaje się mocno wątpliwe, czy możliwe jest stworzenie precyzyjnej definicji w tym zakresie. Istotniejsze znaczenie ma jednak funkcja ochrony realizowanej za pomocą form określonych w ustawie o ochronie przyrody. Intensywność i zakres tej ochrony nie powinny bowiem, jak się wydaje, ulegać zróżnicowaniu w zależności od tego, czy w grę wchodzi przestrzeń objęta obszarami wiejskimi, czy innymi, zwłaszcza jeśli zważyć, że nadawanie statusu obszarów „,miejskich” następuje z uwzględnieniem nader nieostrych kryteriów. ${ }^{45}$ Konstatacja ta nie oznacza jednak, że obowiązujący stan prawny nie nasuwa żadnych zastrzeżeń. Do rozważenia pozostaje bowiem zwiększenie ,elastyczności” reżimu prawnego niektórych form ochrony obszarowej, które to spostrzeżenie dotyczy przede wszystkim parków narodowych i rezerwatów przyrody. Odrębną kwestią jest też potrzeba ustawowego ukształtowania reżimu prawnego otuliny. ${ }^{46}$ Aktualnie bowiem jest on regulowany wybiórczo w niektórych przepisach szczególnych, ${ }^{47}$ brak natomiast $\mathrm{w}$ tym zakresie generalnych rozwiązań wynikających z ustawy o ochronie przyrody. ${ }^{48}$

17. Jeśli z kolei chodzi o drugie ze sformułowanych na wstępie pytań, to wydaje się, że przepisy ustawy o ochronie przyrody co do zasady realizują dyrektywę zrównoważonego rozwoju, mimo że sam termin nie pojawia się w przepisach tej ustawy. Przede wszystkim więc odnotować należy, że w przestrzeni tej dochodzi do mniej lub dalej idącego ,integrowania” różnego rodzaju form działalności, co oznacza, że jedna z nich nie dominuje w sposób absolutny, wykluczając wszystkie pozostałe. Taki stan rzeczy stanowiłby bowiem zaprzeczenie integracji i oznaczałby w istocie rzeczy zahamowanie, a w wielu przypadkach wręcz unicestwienie rozwoju społeczno-gospodarczego. Jest przy tym oczywiste, że funkcja ochronna, jaką realizują

Por. art. 4 ustawy z dnia 8 marca 1990 r. o samorządzie gminnym (tekst jedn. Dz.U. z 2016 r., poz. 446 ze zm.) oraz rozporządzenie Rady Ministrów z dnia 9 sierpnia 2001 r. w sprawie trybu postępowania przy składaniu wniosków dotyczących tworzenia, łączenia, dzielenia, znoszenia i ustalania granic gmin, nadawania gminie lub miejscowości statusu miasta, ustalania i zmiany nazw gmin i siedzib ich władz oraz dokumentów wymaganych w tych sprawach (tekst jedn. Dz.U. z 2014 r., poz. 310). Stosownie do treści art. 5 pkt 14 u.o.p., 14) otulina stanowi strefę ochronną graniczącą z formą ochrony przyrody i wyznaczoną indywidualnie dla formy ochrony przyrody w celu zabezpieczenia przed zagrożeniami zewnętrznymi wynikającymi z działalności człowieka. W aktualnym stanie prawnym jest ona obowiązkowo wyznaczana w przypadku parku narodowego (art. 11 ust. 1 u.o.p.), fakultatywnie natomiast w przypadku rezerwatu przyrody (art. 13 ust. 2 u.o.p.) oraz parku krajobrazowego (art. 16 ust. 2 u.o.p.).

47 Na co trafnie zwróciła uwagę M. Szalewska (por. Otulina parku narodowego - charakter prawny i funkcje, [w:] Ocena stanu prawnego..., op. cit., s. 175 i n.).

48 Por. R. Mikosz, Otulina parku narodowego - wybrane zagadnienia prawne, [w:] Ocena stanu prawnego..., op. cit., s. 159 i n. oraz T. Zyglewska, Charakter prawny otuliny parku narodowego, tamże s. 186 i n. 
obszarowe instrumenty ochrony przyrody sprawia, iż ma ona charakter dominujący, czasem jednak - o czym była mowa wyżej, następuje swego rodzaju „odwrócenie priorytetów". 


\section{NATURE PROTECTION IN RURAL AREAS. SELECTED ISSUES}

Keywords: Environmental protection, rural area, sustainable development

The study is to consider two issues in the field of nature conservation. The first of them comes down to the question, whether the legal regulation concerning the area forms of nature protection is a kind of universal, or contains specific instruments relating only to rural areas. The second of the issues raised, is an attempt to answer the question of whether the legal regulation concerning the protection of nature can be seen as implementing the principle of sustainable development, especially in relation to rural areas. The analysis leads to the conclusion that the legislature does not provide ,special” regime of nature conservation in rural areas, and the provisions of the Nature Conservation Act in principle implement the directive sustainable development, despite the fact that the term does not appear in the provisions of this Act.

\section{Bibliografia:}

Bukowski Z., Konstytucyjne podstawy obowiązków państwa w zakresie ochrony środowiska, „Prawo i Środowisko" 2002 r., nr 4.

Bukowski Z., Zrównoważony rozwój w systemie prawa, Toruń 2009.

Ciechanowicz-McLean J., Urbańska K., Zasada zrównoważonego rozwoju w prawie polskim i międzynarodowym, Gdańsk 2009.

Czech E. K., Ograniczanie wolności działalności gospodarczej na obszarach Natura 2000, [w:] Problemy wdrażania systemu Natura 2000 w Polsce, A. Kaźmierska-Patrzyczna, M.A. Król (red.), Szczecin - Łódź - Poznań 2013.

Dobrowolski G., Mikosz R., Zasada zrównoważonego rozwoju w orzecznictwie sądów administracyjnych, [w:] Działalność gospodarcza na obszarach chronionych, R. Biskup, M. Pytel, R. Rudnicki, J. Trzewik (red.), Lublin 2014.

Dobrowolski G., Lipiński A., Mikosz R., Radecki G., Zrównoważony rozwój jako czynnik determinujący prawne podstawy zarządzania geologicznymi zasobami środowiska, G. Dobrowolski (red.), Katowice 2016.

Górski M., Pchałek M., Radecki W., Jerzmański J., Bar M., Urban S., Jendrośka J., Prawo ochrony środowiska. Komentarz, Warszawa 2011.

Gruszecki K., Ustawa o ochronie przyrody. Komentarz, Wydanie III, LEX 2013, (wydanie elektroniczne).

Gruszecki K., Ograniczenia prawne w realizacji inwestycji w związku z wyznaczeniem obszarów Natura 2000, „Zeszyty Naukowe Sądownictwa Administracyjnego” 2011, nr 2.

Habuda A., Ochrona przyrody a działalność gospodarcza na obszarach Natura 2000, [w:] Gospodarcze prawo środowiska, J. Ciechanowicz-McLean, T. Bojar-Fijałkowski (red.), Gdańsk 2009. 
Lipiński A., Park narodowy jako forma ochrony przyrody. Krytyczna analiza stanu prawnego, [w:] Ocena stanu prawnego funkcjonowania polskich parków narodowych, Warszawa 2015.

Mikosz R., Otulina parku narodowego - wybrane zagadnienia prawne, [w:] Ocena stanu prawnego funkcjonowania polskich parków narodowych, Warszawa 2015.

Mordasiewicz-Toczyska K., Prawne aspekty tworzenia, likwidacji i zmiany granic parku narodowego, [w:] Ochrona przyrody. Uwarunkowania prawne, organizacyjne, społeczne i intelektualne wykorzystywania jej zasobów, Warszawa 2015.

Prawo ochrony środowiska, J. Stelmasiak (red.), Warszawa 2010.

Radecki W., Ustawa o ochronie przyrody. Komentarz, Wydanie III, Warszawa 2012.

Szalewska M., Otulina parku narodowego - charakter prawny i funkcje, [w:] Ocena stanu prawnego funkcjonowania polskich parków narodowych, Warszawa 2015.

Winczorek P., Komentarz do Konstytucji Rzeczypospolitej Polskiej z dnia 2 kwietnia 1997 r., Warszawa 2000.

Zyglewska T., Charakter prawny otuliny parku narodowego, [w:] Ocena stanu prawnego funkcjonowania polskich parków narodowych, Warszawa 2015. 